\title{
Ale światy są tendencyjne
}

\author{
Agata Fiedotow
}

\begin{abstract}
Abstrakt: Autorka opisuje znaczenie pojęcia „powieści tendencyjnej”, jak również jego szczególne użycie w polskiej teorii literatury w kontekście powieści socrealistycznej. W odniesieniu do koncepcji ideologii Louisa Althussera oraz teorii gustu czystego/nieczystego Pierre’a Bourdieu autorka kwestionuje ideę „tendencyjności" w dyskursie, a co za tym idzie, stawia pod znakiem zapytania również zasadność określania powieści „mocno nasyconych ideologią” mianem „tendencyjnych”. Inspiracją do napisania artykułu był odbiór w Polsce realizmu socjalistycznego, a w szczególności powieści czasu stalinizmu, których zapomniany sens oraz uniwersalną metaforykę autorka przedstawia w niniejszej pracy.

Wyrażenia kluczowe: powieść tendencyjna, socrealizm, ideologia, niesmak, przemiana świata
\end{abstract}

„A zatem dlaczego Słowacki wzbudza w nas zachwyt i miłość? [...] Hm... dlaczego? Dlatego, panowie, że Słowacki wielkim poetą był!

Wałkiewicz! Dlaczego? Niech Wałkiewicz powtórzy - dlaczego? Dlaczego zachwyt, miłość, płaczemy, poryw, serce i lecieć, pędzić?"

Witold Gombrowicz, Ferdydurke (Gombrowicz, 1987, s. 42)

Nad „tendencyjną” prozą stalinizmu z zachwytem nie pochylił się nie tylko żaden belfer, ale przez ponad trzydzieści lat od jej powstania - nawet żaden akademik. Nie zachwyca i już! Socrealizm stał się inspiracją trudnej dziś do określenia liczby schematycznych fabuł, wypełnionych przodownikami pracy i zatwardziałymi wrogami „nowego ładu”. Żadna jednak z nich nie zapisała się na trwałe w polskiej kulturze. Bo kto dziś słyszał o Lewantach Andrzeja Brauna (Braun, 1954), Węglu Aleksandra Ścibora-Rylskiego (Ścibor-Rylski, 1952), Mądrych ziołach Wiktora Żukrowskiego (Żukrowski, 1953) czy nawet Obywatelach Kazimierza Brandysa (K. Brandys, 1955) i Pamiątce z Celulozy Igora Newerlego (Newerly, 1953)? Bo czy one „polskie”? Bo czy nadają się do „kultury”?

Jak postulował Stefan Żółkiewski na łamach „Kuźnicy”, socrealistyczna literatura miała być „świadomie zaangażowana na równi z innymi społecznymi siłami postępu we współczesną walkę klasową" (Tomasik, 1991, s. 14). Szczególna rola w tym procesie przypadała pisarzowi:

„Obowiązkiem twórcy, kształtującego duchową dziedzinę życia narodu, jest wczuć się w tętno pracy mas ludowych, w ich tęsknotę i potrzeby, z ich wzruszeń i przeżyć czerpać natchnienie twórcze do własnego wysiłku, którego celem głównym i podstawowym winno być podniesienie i uszlachetnienie poziomu życia tych mas. Twórczość oderwana od tego celu, 
sztuka dla sztuki, wynika z pobudek aspołecznych [...] Trzeba, żeby nasi twórcy współcześni pamiętali, że ich dzieła powinny kształtować, porywać i wychowywać naród"1.

Pisarza obowiązywała tzw. postawa partyjna oznaczająca opisywanie świata w sposób, jaki nakazuje partia, zgodnie z zasadami tzw. rozwoju społecznego narzuconymi przez materializm historyczny. Wiązano to z zasadą „typowości”, wbrew potocznemu rozumieniu oznaczającą nie uśredniony, lecz postulowany obraz rzeczywistości. Program zakładał także tzw. przełom tematyczny, kierując uwagę twórców przede wszystkim na realizację planu sześcioletniego: budownictwo, rozwój przemysłu czy kolektywizację wsi.

Socrealizm, wprowadzony do literatury decyzją zjazdu szczecińskiego Związku Literatów Polskich obowiązywał przez cały okres planu sześcioletniego aż do symbolicznego momentu publikacji Poematu dla dorostych Adama Ważyka na łamach „Nowej Kultury” w 1955 roku. Gdy wraz z odwilżą stopniowo znikał stalinowski terror, socrealistyczna twórczość w świadomości polskiej inteligencji stawała się synonimem „sztuki zdegradowanej” (Głowiński, 1992) czy, jak mówił Zbigniew Herbert, przykładem „zbrodni, która dokonała się na kulturze" (Bikont \& Szczęsna, 2006, s. 493).

Powojenna inteligencja, skompromitowana udziałem w socjalistycznym planie inżynierii dusz, okresem minionym zajmowała się niechętnie. Pisząc o socrealizmie na początku lat dziewięćdziesiątych, Michał Głowiński przede wszystkim czuł potrzebę usprawiedliwienia tej decyzji:

„Muszę się wytłumaczyć z podjęcia tego właśnie tematu, spotykałem się bowiem z apodyktycznie formułowaną opinią, że czymś takim zajmować się nie warto. Otóż pozwalam sobie myśleć inaczej. Rzeczywiście socrealizmem zajmować się nie warto wówczas, gdy naukę o literaturze, a jej historię przede wszystkim, pojmuje się wyłącznie jako bezpośrednie mówienie o wartościach, a więc o arcydziełach i zjawiskach znaczących. Socrealizm jest antywartością, musiałby przeto zniknąć z pola widzenia" (Głowiński, 1992, s. 5).

Badacze systematycznie wypełniali lukę, którą wokół socrealizmu w nauce wytworzyły okoliczności polityczne, jednak specyfika socrealizmu jako tematu wciąż pozostaje „czymś”, co rozumie się samo przez się. Ewa Toniak, autorka opracowania Olbrzymki: kobiety i socrealizm, podkreśla, że jako badaczka socrealizmu „nie obraża się i nie wystawia ocen”, zakładając intuicyjną wiedzę czytelnika o tym, iż ocena - w dodatku negatywna - ma być domyślną reakcją na socrealizm (Toniak, 2008).

Kiedy się obserwuje dyskurs o socrealizmie, nie sposób pominąć milczeniem paradoksalnej sytuacji, w której jego komentatorzy (nie wyłączając autorki niniejszego tekstu), formułując główny zarzut wobec socrealistycznej twórczości lub tylko będąc jego świadomi, w sposób nieunikniony potwierdzają swój udział w „ideologiczności”, na temat której się wypowiadają.

Socrealizm oskarża się o „propagandę”, podporządkowanie polityce państwowej i współtworzenie totalitarnych mechanizmów zniewalania. Rzecz nie w tym, żeby

1 Z przemowy Bolesława Bieruta podczas otwarcia wrocławskiej radiostacji (Tomasik, 1988, s. 10). 
zaprzeczać, lecz by zastanowić się nad sensem podnoszonych przeciw niemu zarzutów. Wskazują one bowiem na zjawisko znacznie przekraczające ponad półwieczne zmagania Polaków z „obcym” ustrojem: zaprzeczanie obecności ideologii w dowolnym dyskursie, a w konsekwencji wykorzystywanie „ideologiczności” jako podstawowego argumentu przeciw swym - skądinąd ideologicznym - antagonistom.

W świat socrealistycznej powieści nie sposób wejść, nie odnosząc się do jej percepcji w polskiej świadomości, a tym samym nie podejmując próby zrozumienia sensu „tendencji” uważanej za jeden z podstawowych wyróżników twórczości okresu stalinowskiego. Gatunek powieści tendencyjnej oraz problem „tezy” i „ideologii” w dyskursie będą przedmiotem pierwszej części tekstu. Druga będzie próbą odczarowania socrealistycznych światów przedstawionych z odniesieniem do tych wątków, których osobliwość na swój sposób może „zachwycać”.

\section{Wokót powieści tendencyjnej}

Istnienie określenia „powieść tendencyjna” ma odróżniać „tendencyjne” czy, mówiąc inaczej, „posiadające tezę" utwory od wszystkich innych powieści. Teoretycy literatury przekonują, że podstawą tej różnicy jest oparcie prozy na pewnej ideologii. Słownik terminów literackich podaje, że powieść tendencyjna to „odmiana powieści, w której świat przedstawiony i sposób rozwijania narracji podporządkowane są przyjętym przez autora założeniom ideologicznym bądź politycznym o charakterze doraźnie aktualnym" (Sławiński, 1988, ss. 387-388). Wojciech Tomasik dodaje do tego: świat przedstawiony oparty na dualistycznym systemie wartości, obecność apelu skierowanego do odbiorcy, jak też doktrynalny intertekst, wymuszający prawidłowe odczytanie powieści. Wymienia ponadto cechy szczególne polskiej prozy okresu 1949-1955. Po pierwsze, jest to stosowanie środków stylistycznych, które pozwalają na powiązanie treści propagowanych z systemem funkcjonujących stereotypów społecznych głównie poprzez struktury kliszowe, co jako nośnik potocznej wiedzy pozwala asymilować nową rzeczywistość do schematów znanych odbiorcy. Po drugie, respektowanie kompetencji literackich odbiorcy poprzez wykorzystywanie skonwencjonalizowanych układów literackich, jak np. schemat miłości z przeszkodami. Po trzecie, to stosowanie struktury parataktycznej - konstruowanie fabuły w taki sposób, że kolejne składniki ciągu zdarzeń nie łączy relacja przyczynowo-skutkowa, lecz relacja powtarzania tej samej myśli; w przypadku konstrukcji bohaterów ich charakterystyka powtarza się w opisie zdarzeń, w jakich uczestniczą, oraz poprzez użycie znaczących imion. I wreszcie - zacieranie w wypowiedzi jej perswazyjnego i kliszowego charakteru (Tomasik, 1988, ss. 29-31).

Trudno kwestionować fakt, że są to cechy większości powieści czasów planu sześcioletniego, ale trudno jednocześnie zaprzeczyć, że są to również właściwości wielu innych gatunków literackich. Odwoływanie się do stereotypów, posługiwanie kliszami literackimi, a nawet konstruowanie fabuły i postaci w oparciu o powtarzaną myśl przewodnią 
nie jest niczym szczególnym dla socrealizmu. Wśród utworów, które noszą takie cechy, można bez zastanowienia wymieniać literaturę dziecięcą, różne rodzaje pisarstwa deklarującego się jako „dydaktyczne” lub „polityczne”, czy wreszcie bardzo obszerną i trudną do jednoznacznego określenia literaturę kierowaną do tzw. mniej wymagających czytelników. Ponadto jeśli przyjrzeć się ostatniemu z wymienionych przez Wojciecha Tomasika elementów, tj. „zacieraniu w wypowiedziach ich perswazyjnego charakteru”, można zapytać, czy te utwory, w których perswazyjności nie dostrzegamy, nie są przypadkiem najdoskonalszymi w swej kategorii - „powieści tendencyjnych”?

\section{Szwedzka skuteczność}

„[...] metody nasze wyrabiania pupy nie mają sobie równych, a ciało nauczycielskie pod tym względem dobrane jest jak najstaranniej. Czy chciałby pan zobaczyć ciało?"

Witold Gombrowicz, Ferdydurke

(Gombrowicz, 1987, s. 37)

Próbując zatem odpowiedzieć na pytanie, czym jest „literatura tendencyjna”, należałoby zapytać, co odróżnia ją od jakiejkolwiek innej literatury - literatury po prostu. Główny bohater bestsellerowej szwedzkiej trylogii kryminalnej Millenium, dziennikarz śledczy i feminista przypominający samego autora, Stiega Larssona, tropi „mężczyzn nienawidzących kobiety”, czyli seryjnych gwałcicieli i morderców. Bohaterka kryminalnej sagi Camilli Läckberg dyskutuje o konsekwencjach faszyzmu czy potrzebie zaangażowania ojców w wychowanie dzieci w trakcie kolejnych śledztw.

Można wymienić jeszcze przynajmniej kilku czytanych na całym świecie szwedzkich autorów, jak Henning Mankell czy Leif G. Persson, którzy w swej twórczości odnoszą się do społeczno-politycznych problemów dzisiejszej Szwecji. Współczesny kryminał, nazwijmy go socjaldemokratycznym, dobrze sprawdza się jako fabularny głos w dyskusjach lewicy nad „patriarchalnym” modelem społeczeństwa czy rosnącym w siłę skandynawskim neonazizmem, wrogim wobec wartości liberalnych demokracji.

Jeśli wziąć pod uwagę milionowe nakłady, niemal „produkcyjne” tempo powstawania kolejnych tomów, dosyć schematyczne fabuły oraz polaryzację postaw bohaterów - prawych inspektorów, godzących pracę detektywistyczną z obowiązkami ojcowskimi, którzy zmagają się ze złoczyńcami powodowanymi niechęcią do kobiet i pedofilami, wyłudzającymi świadczenia od ubezpieczycieli, a w dodatku niesegregującymi śmieci - trudno pominąć analogię z polską twórczością lat pięćdziesiątych. Dodać można jeszcze, że szwedzkie kryminały doskonale spełniają rolę „wytwórczą”, nie tylko przyczyniając się do wzrostu sprzedaży powieści sensacyjnych na światowych rynkach, ale i przyciągając do Skandynawii klientów nowej branży - turystyki kryminalnej, którzy podróżują szlakiem powieściowych bohaterów (Walat, 2013).

Można zaprzeczać podobieństwu, twierdząc, że oba gatunki różnią się co do istoty literatura socrealistyczna zaistniała dzięki politycznym decyzjom i cała jej moc w tych

SLH 2/2013 | str. 379 
decyzjach właśnie tkwiła, zaś szwedzki „kryminał socjaldemokratyczny” to nie „systemowa propaganda", lecz - pomimo wyrazistych poglądów - efekt suwerennych decyzji autorów. Przecież szwedzki system polityczny nawet nie rozważa możliwości tworzenia literatury mocą królewskiego dekretu. Któż więc lepiej go uprawomocni, jeśli nie pisarz, który korzystając z wolności słowa, podejmie temat przypadkiem aprobowany przez większość parlamentarną oraz niemal każdego Szweda?

Jeśli dodamy do tego oburzenie, jakie wśród Szwedów wywołała królowa Sylwia, ośmielając się naruszyć suwerenność literatury takimi oto słowami skierowanymi do polskich studentów skandynawistyki: „Pamiętajcie, że kryminały są wytworem wyobraźni. Dla mnie społeczeństwo szwedzkie jest znacznie bardziej ciepłe niż ten ponury obraz, jaki tworzą" (Walat, 2013), otrzymamy poziom skuteczności reprodukcji społeczno-kulturowej, o jakim socrealistyczni „ideologowie” mogli tylko pomarzyć.

Szwedzki przykład jest dobry dlatego, że dzięki zestawieniu z twórczością socrealistyczną pozwala przedstawić mechanizm funkcjonowania „ideologii” na dwóch biegunach: w warunkach tzw. demokracji liberalnej (gwarantującej wolności obywatelskie) i systemu z założenia godzącego w prawa jednostki. Wykazuje przy tym zdecydowaną przewagę tego, który - mówiąc językiem Pierre’a Bourdieu - najlepiej ukrywa układy sił leżące u podstaw. Ma też niewątpliwą wadę: przedstawiony wraz z literaturą stalinowską może mylnie sugerować, że „ideologiczność” to szczególna przypadłość twórczości „lewicowej”.

Zostawmy jednak szwedzkie kryminały, bo nie o nich tu przecież mowa. Chodzi przede wszystkim o wskazanie na dyskretną moc oddziaływania ideologii, najskuteczniejszej, gdy dobrze ukryta².

„Powieścią tendencyjną” nazwiemy przede wszystkim taki utwór, którego „tendencję” jesteśmy w stanie dostrzec. Umiejętność jej dostrzeżenia ograniczają jednak podstawowe właściwości samej ideologii. Jak pisze Louis Althusser, „ci, którzy tkwią w ideologii, uważają z definicji, że sami znajdują się poza nią: jednym z rezultatów ideologii jest praktyczne «zanegowanie» ideologicznego charakteru ideologii przez ideologię: ideologia nigdy nie mówi: «jestem ideologiczna»" (Althusser, 2006, s. 24).

Oddziaływanie ideologii jest najskuteczniejsze wówczas, gdy intuicyjnie przyjmujemy pewien system wartości, zapominając o jego źródle i okolicznościach przyswojenia; wówczas, gdy przemoc symboliczna maskuje nie tyle represyjność instytucji oficjalnie z represją kojarzonych, ile przede wszystkim samą siebie. Tylko wtedy proces reprodukcji społeczno-kulturowej osiąga poziom zapewniający ciągłość ideologicznej „oczywistości". Poczucie oczywistości eliminuje więc także zdolność do identyfikacji tendencji w literaturze, sprawiając, że „powieść tendencyjna” w powszechnym odczuciu staje się po prostu „powieścią”.

2 Przy czym „ukrycie” pozostaje względne - czasem wystarczy zapewnienie o obowiązującej wolności słowa i wciągająca fabuła, by „powieść z tezą” stała się bestsellerem. 


\section{Niesmak?}

"- Jak to mnie zachwyca, kiedy mnie nie zachwyca?

- Jak to nie zachwyca Gałkiewicza, jeśli tysiąc razy tłumaczyłem Gałkiewiczowi, że go zachwyca?"

Witold Gombrowicz, Ferdydurke

(Gombrowicz, 1987, s. 43)

Przychodzi powrócić jeszcze do kategorii „czytelników mniej wymagających”. Im bardziej niesztuką (niewartością) jest socrealizm, tym bardziej nie można mówić o nim, pomijając kwestię estetyki i, siłą rzeczy, gustu. O gustach dobrze wychowani ludzie podobno nie dyskutują, ale, jak zauważa Bourdieu, „nie dlatego, że każdy ma swój gust, ale dlatego, że każdy gust uważa, że jest ufundowany w naturze - jest habitusem; w efekcie odrzuca inne jako skandal wynaturzenia" (Bourdieu, 2005, ss. 74-75). Owym skandalem wynaturzenia w dowolnym „obcym” dyskursie staje się więc „teza”, „tendencja”, której nie ma w przestrzeni („naszej”) normy - w „naszym” habitusie. Wskazanie „tezy” w socrealistycznej powieści przychodzi z intuicyjną łatwością, z jaką zwykło się dostrzegać odstępstwo od normy, „naszej” i „swojskiej”. Jednak nie w samej sprzeczności między „tezą” a „normą” (habitusem), a zatem nie w zdolności do zidentyfikowania „obcego” światopoglądu w literaturze, leży przyczyna zaklasyfikowania danego dzieła literackiego jako tendencyjnego. Dostrzeżenie „obcej” ideologii, czyli, mówiąc za Althusserem, po prostu „ideologii”, istotnie pozwala podmiotowi tego procesu wyznaczyć granicę pomiędzy „swoim” i „obcym”.

Ta granica i dokonujący się poprzez wskazanie ideologii proces autoidentyfikacji nie są tym samym, czym wypominanie ideologii, które towarzyszy rozpoznaniu literatury jako tendencyjnej. Literatura z tezą to coś znacznie więcej niż literatura, w której dostrzeżono „ideologię”; to raczej literatura, którą na owej „ideologiczności” przyłapano, co gorsza, bez większego trudu. Nadanie powieści miana „tendencyjnej” niesie w sobie negatywną ocenę, co wynika nie tyle z dostrzeżenia jej ideologicznego „wynaturzenia”, ile przede wszystkim ze specyfiki aktu demaskacji, który mu towarzyszy. Utwór zaklasyfikowany jako mający tezę równocześnie zostaje uznany za stojący w sprzeczności z toposem dzieła sztuki jako takiego, u którego źródeł w powszechnym przekonaniu leży autorskie natchnienie, a nie decyzja administracyjna. Nieudolne „oszustwo” narratora, który w miejsce spodziewanej „fabuły” podkłada „tezę”, zostaje wykryte. Ujawnienie „prawdziwych” intencji dzieła jako „politycznych”, a nie „czysto literackich”, zdaje się uwydatniać jego artystyczną miernotę.

Demaskacja jest dla czytelnika podwójnie dotkliwa. Po pierwsze dlatego, że przyłapuje on narratora na „tanich”, łatwych do ujawnienia trikach „ideologicznych”, o których Pierre Bourdieu pisze, że „potępia się [je] jako «niskie», «uwłaczające», «hańbiące», gdyż dają widzowi poczucie, że traktowany jest jak pierwszy lepszy, jak ktoś kogo można zwieść za pomocą tandetnych chwytów” (Bourdieu, 2005, s. 598). Po drugie dlatego, że odkrywa, iż sedno tkwi nie tyle w samych technikach „ideologizacji”, ile w świadomej i systemowej gloryfikacji „prymitywizmu” jako odpowiadającego jego („niskim”) gustom/ kompetencjom. Socrealizm, w sposób rewolucyjny opowiadając się przeciw kanonom społecznie 
ukonstytuowanego „smaku”, czyni „pięknym”, „czystym”, „wysokim” to, co tradycyjny zmysł zwykł nazywać barbarzyństwem. W próbie usankcjonowania odwrócenia ról w grupach dominujących i zdominowanych nie ma jednak szans powodzenia. Urażając swych adresatów, w istocie jedynie uprawomocnia dystynkcję epoki z jego perspektywy minionej. Co więcej zaś sprawia, że jawnie „propagandowej” siły jego wytworów boimy się bardziej niż „wielkiej literatury”.

\section{Wielka odnowa: Jak to nie zachwyca?}

Warto jednak zamienić czytelniczą dumę na ciekawość po to tylko, by wejść w świat socrealistycznej prozy, zarazem fascynującej plastycznością swej metaforyki, jak i odpychającej niebezpieczną swobodą stapiania „starego" z „nowym”. Infantylne fabuły i nieporadnie konstruowani bohaterowie, gdy tylko zapomnimy, że powstali, by nas zwieść, mają swój urok.

Druga część tekstu będzie próbą wejścia w światy przedstawione stalinowskich powieści. Gdyby jej celem miałoby być wprowadzenie w specyfikę prozy socrealistycznej na kilku zaledwie stronach, byłoby to zadanie przynajmniej niezwykle nużące, jeśli nie bezsensowne zważywszy na istniejące opracowania. Dlatego poniższe akapity będą jedynie zaproszeniem do lektury, wystosowanym przez współczesną czytelniczkę. Przywołane w kolejnych częściach fragmenty prozy posłużą konfrontacji „inności” socrealistycznych fabuł ze współczesnym „gustem”. Dobór fragmentów i propozycje ich interpretacji trudno uznać za wyczerpującą odpowiedź na pytanie, czym jest socrealizm w percepcji współczesnego czytelnika. Stanowią raczej zbiór arbitralnie wybranych wątków, które mogą na swój sposób „zachwycać”, „porywać” czy „oburzać”. Wśród nich najwięcej uwagi poświęcono socjalistycznemu równouprawnieniu kobiet, które jest fascynujące w swej wewnętrznej sprzeczności, tak dalekiej od dzisiejszego trzeciofalowego feminizmu.

Z pewnością nie będzie to ten „zachwyt”, jaki zarezerwowaliśmy dla klasyków, zachwyt wedle tradycyjnego smaku, w przypadku którego, parafrazując Gombrowicza, „piękne” i godne uwagi jest to, co ... „piękne”, a „wielkim” ten utwór, który jest ... „wielki”. Będzie to raczej „zachwyt” naszych czasów, który potrafi być poszukiwaniem osobliwości, niejednokrotnie na granicy turpistycznej fascynacji brzydotą i pokracznością. Będzie to „zachwyt”, w którym na swój sposób zrealizuje się socrealistyczny postulat rewolucji smaku, a jednocześnie będzie to „zachwyt” o pewnym potencjale poznawczym. Czy jednak nie ztudnym?

Stalinowską prozę czyta się przede wszystkim jako opowieść o wielkiej przemianie, w której dominuje metaforyka początków nowego ustroju, z trudem kształtującego się na gruzach starego świata. Jednym z takich przykładów jest opowieść Janusza Meissnera o gdyńskim trawlerze - „Samsonie”, którego polimorficzność - zwierzęca nieporadność połączona z człowieczą godnością - przywołuje wyobrażenia mitologicznych prapoczątków. 
„Dziób wynurzył się zupełnie [...]. - Jeszcze trochę! Jeszcze! - wołał Roman, cofając się po belkach pochylni, podczas gdy dziób Samsona zdawał się nacierać na niego całym swoim ogromem, wzniesiony wysoko nad nim jak jakiś potwór przedpotopowy, który wynurzył się z morza, niebacznie zwabiony na ląd przez człowieka" (Meissner, 1952, ss. 128, 125).

„Samson” - zwierzę - ptak - człowiek - bestia to jeszcze nieukształtowany byt, pokraczny, ale noszący w sobie zarodki wszystkich przyszłych istnień. Jako narzędzie pracy i żywiciel, dom i schronienie na morzu przypomina uświęcone narzędzia pracy - bóstwa dające życie całej społeczności. Szczególna moc Samsona nie jest jednak - jak w świecie biblijnym - oznaką boskiej przychylności, lecz skumulowaną w wielorybim brzuchu mocą całej załogi. Meissnerowski okręt przypominający starotestamentową wielką rybę, noszącą w brzuchu Jonasza, podobnie jak wiele innych ówczesnych fabuł nawiązuje do topicznego motywu socrealistycznej prozy - odrodzenia.

Socrealistyczne fabuły, proponując własną wersję odnowy rzeczywistości, często podejmują dialog z tradycją chrześcijańską. Bohater powieści Zofii Dróżdż-Satanowskiej, mierząc się z boskim porządkiem, wedle którego od wieków toczy się życie w jego rodzinnej wsi, sam wchodzi w rolę Boga - kreatora marksistowskiego świata. Na początku Opowieści wierzbowej czytamy: „Wiktor Jasienkowski z niewielką walizką w ręku zbliżał się do Łysej Wsi. Rozproszone w mroźnym powietrzu złote pasemka światła czyniły świat uroczystym, świątecznym i poważnym. Na wielkiej płaszczyźnie rzędami kucnęły chaty, Wiktor Jasienkowski wymówił prawie głośno: - Wieś” (Dróżdż-Satanowska, 1953, s. 9). Wejście Wiktora jest „uroczyste, świąteczne i poważne”, takie jakie może być wejście mieszkańca tradycyjnej wspólnoty do kościoła w dniu ważnej uroczystości. Wiejskie chaŁupy „kucające rzędami” w zimowym pejzażu przypominają wiernych klękających w drewnianych ławkach, ustawionych rzędami przed ołtarzem. To święto to nowy początek, to ponowne stworzenie, które się dokonuje dzięki jednemu słowu: „Wieś”. „Ozłacająca” moc światła przydaje rzeczywistości odświętny charakter, nawiązując do upragnionego bogactwa, które w nowym świecie ma być udziałem wszystkich. Twórca nowego porządku, jak wszyscy „typowi” po engelsowsku socrealistyczni bohaterowie, jest w tej roli zarazem nadludzkim kreatorem i zwykłym członkiem wspólnoty: Człowiekiem takim jak inni, mieszkańcem Wsi - Świata.

Gdy w tej samej powieści jeden z parobków decyduje się wstąpić do spółdzielni, czytamy: „Gdyby go wówczas ktoś zobaczył, byłby się zdziwił niepomiernie. Garb bowiem z jego pleców gdzieś znikł, Michel ${ }^{3}$ wyprostował się i kiedy w kościele dzwony ostrym głosem dzwoniły na podniesienie, on oparłszy się o węgieł chaty zaśpiewał nagle cichym, ale ładnym, młodym głosem piosenkę, jakiej tu nikt nie znał: «Dana, moja dana, wzieni diabli pana,/ Wzieni go i niesum, parobki się ciesum», po czym spokojnie, pewnym krokiem udał się w stronę wierzb [gdzie mieściła się spółdzielnia, ale także, zgodnie z ludową tradycją, mieszkało licho - A.F.]" (Dróżdż-Satanowska, 1953, s. 92). Obraz parobka

3 Obco brzmiące imię parobka, jak tłumaczy narrator, pochodzi z czasów niemieckiej okupacji, kiedy cudzoziemscy panowie zmienili jego prawdziwe imię „Michał” na „Michel”. Wydaje się, że w powieściowej fabule to jedna z oznak służących przedstawianiu, mówiąc językiem marksistowskim, „alienującej” siły pańskiej władzy, może też być śladem przemiany, jakiej dawny świat poddał parobka. 
oddającego się na służbę diabłu, czyli... do spółdzielni, to z jednej strony oczywista kpina z wiejskich lęków przed nowym porządkiem, z drugiej zaś nawiązanie do tradycyjnych ludowych powiedzeń [na przykład „Bierz diable, co twego” czy „Bij diabła, aż go czarci wezną" (Krzyżanowski, 1969, s. 425)], sytuujących to, co dobre przy Bogu, zaś to, co złe, przy szatanie.

\section{Kobieta i mężczyzna: pozory równouprawnienia}

„[...] z żoną jest zupełnie jak z zapleczem frontu. Kiedy zaplecze jest mocne - front działa dobrze"

Marian Brandys, Początek opowieści

(M. Brandys, 1953, s. 145)

Równouprawnienie w socrealistycznej prozie realizuje się wyłącznie w obszarach wyznaczonych przez męski świat pracy i jest ściśle reglamentowane: oznacza danie stworzeniu, jakim jest kobieta, prawa do bycia człowiekiem - czyli mężczyzną. Retoryce równouprawnienia towarzyszy więc podtrzymywanie tradycyjnego modelu rodziny. Kobietę, co prawda, wypuszcza się z kuchni, by uczestniczyła w życiu społecznym i zawodowym, do kuchni jednak zawsze musi wrócić. Może wprawdzie jak mężczyzna stać się traktorzystą, murarzem i mechanikiem, pozostaną jej jednak obowiązki domowe: nakarmienie męża i dzieci czy utrzymanie porządku, nie mniej ważne niż obowiązki zawodowe.

Dbać o dom oczywiście trzeba. Na krytykę zasługują więc te bohaterki, które jak Ciapka Migoniowa lekceważą swe powinności:

„Mieszkanie w dalszym ciągu robiło wrażenie koczowiska uchodźców, jakkolwiek Migoniowa z Piotrusiem objęli je we władanie już przed tygodniem. Widelce, tyżki i przybory do mycia wyciągano z walizek, które stały na wszystkich krzesłach. Kontrastowe wrażenie sprawiał stary rozpylacz do perfum z gałką w siateczce i porcelanowa pudernica, ustawione starannie na komodzie" (Ścibor-Rylski, 1952, s. 82).

Ale i przesadna troska o sprawy domowe nie świadczy dobrze o gospodyni:

„Była taka [...] jak żona listonosza Kranca, którą całe życie zajmował tylko problem cerowania skarpetek, jak połowica starzyka z Budeli, której dzień upływał na nieśpiesznym, pedantycznym szatkowaniu cebulki i szczypiorku z doniczki, jak setki tych kobiet, dla których świat był tylko nieciekawym rynkiem z firankami w oknach" (Ścibor-Rylski, 1952, s. 77).

Bohaterkom, które siedzą tylko w domu, grozi nuda i zepsucie. Receptą na kobiece grzechy (próżność, lenistwo i złe prowadzenie się) zawsze staje się praca i zaangażowanie w życie społeczne. Leośka, nieszczęśliwie zakochana w Teofilu, ślamazarna i leniwa, po wyjściu z domu całkiem się odmienia: „Od czasu, kiedy zaczęła pracować w świetlicy, objawiały się w niej niespodziewane tysiące nie przeczuwanych talentów. Leośka kwitła jak młoda matka, której macierzyństwo przywróciło nagle całą powagę i krasę" (Braun, 1954b, s. 220). Nawet jednak uzasadnione wyjścia z domu muszą odbywać się za zgodą 
mężczyzny: „Mam o szóstej zebranie koła rodzicielskiego [...]. Stała przed nim jak grzeczna dziewczynka, która już chce iść na podwórze do gry w klasy" (Ścibor-Rylski, 1952, s. 75).

Te niekontrolowane wyjścia budzą uzasadniony niepokój:

„W mieszkaniu było pusto. [...] Po raz pierwszy od bardzo długiego czasu Jan zastanawiał się, co mogła robić jego żona podczas częstych nieobecności w domu. Gdzie wychodziła? Po co? Do kogo? [...] Przeszedł do drugiego pokoju, w którym pachniało zakurzoną firanką i pudrem. Na tóżku leżały porzucone w pośpiechu części garderoby «na codzień», fartuszek, perkalikowa sukienka, lekko przybrudzona bielizna. Ciapka przebrała się gruntownie przed wyjściem!" (Ścibor-Rylski, 1952, s. 210).

Dom bez żony to nie-dom.

Natomiast dom bez męża to w sytuacji odbudowy kraju stan zupełnie naturalny i, jak tłumaczy żonie Piotr Kulbar, każdy musi ponosić ofiary w związku z planem sześcioletnim, więc żona powinna to zrozumieć (M. Brandys, 1953, s. 123). Jednak większość powieściowych żon tego nie rozumie, podobnie jak nie rozumie swych mężów, a co za tym idzie ustroju. Konflikt małżeński między bohaterem pozytywnym i jego „drobnomieszczańską” żoną o późne lub rzadkie powroty do domu stanowi zupełnie podstawowy motyw fabularny: „Przywitali się. - No i co? Spytała. Uśmiechnął się. - Realizujemy Plan Sześcioletni. - To przez sześć lat będziemy widywali się co dwa tygodnie? Nie miał ochoty do perswazji. [...] Kiedy sięgnęła po płaszcz, zdziwił się. - Wychodzisz?" (Konwicki, 1952, s. 49).

W socrealistycznej prozie nie ma złych mężów, są tylko żony, które ich nie rozumieją. Męskie grzechy - picie i bicie - są udziałem tylko jednego bohatera - Markowskiego z Lewantów. Choć tę postawę krytykują wszyscy towarzysze i grozi mu nawet wyrzucenie z partii, wydaje się, że w powieściowym świecie wartości znajduje ona usprawiedliwienie: „Źle ożeniłeś się. [...] Robotnik nie powinien brać niepracującej kobiety” (Braun, 1954a, ss. 108-109). Odpowiedzialność spoczywa na kobiecie: „nie rozumiała go wtedy, gdy krwią znaczył warszawski bruk, nie rozumiała, czemu dusił się przez te lata szabru i nudów [...]. O jakże lekkomyślne są kobiety, które, gdy mężczyzna chce z nimi dyskutować, zamykają mu usta pocałunkiem!" (Braun, 1954a, s. 106).

Wydaje się, że socrealistyczny mąż nie ma obowiązków względem rodziny. Swoją powinność wobec kraju, także wobec najbliższych, realizuje, pracując na budowie czy w kopalni. Kiedy Kulbar, chcąc wynagrodzić żonie nieobecność w domu i trudne warunki życia, codziennie rano rozpala w piecu i kupuje mleko dla dziecka, zostaje upomniany przez majstra Walaszczyka, który twierdzi, że przewodniczącemu ZMP to się zwyczajnie nie godzi (M. Brandys, 1953, s. 129). Co nie znaczy, że mężczyzna nie wtrąca się w sprawy domowe. Przeciwnie, w nowym świecie dom to nie tylko „babska sprawa”. Gdy trzeba, mąż nawet groźbą siły egzekwuje w nim posłuszeństwo:

"- Dasz jeść?

- Aaa, jeść to chcesz, a wszystko inne cię nie obchodzi... Hotel, co hotel chcesz mieć w domu, mężulku? [...] Migoń zacisnął szczęki i wciągnął nosem powietrze. Żona wiedziała już, co to znaczy, toteż wstała i wreszcie poszła do kuchni” (Ścibor-Rylski, 1952, s. 81). 
Interesującej metaforyki relacji kobieta - mężczyzna dostarcza zdrada małżeńska, która przedstawiana jest jako rodzaj współpracy z wrogiem, szczególnie niebezpiecznej w sytuacji walki, codziennego stanu powieściowej rzeczywistości. Bohater Węgla, Jędraszko, od czasu wyrzucenia kochanka żony z mieszkania żyje w ciągłym niepokoju, podejrzewając Martę o kolejne zdrady. Pewnego razu, chcąc przyłapać małżonkę na gorącym uczynku, wraca wcześniej do domu i zamiast w objęciach innego mężczyzny znajduje ją przy swej własnej biblioteczce. Pojednanie przypomina przywrócenie panowania prawowitego władcy:

„Jędraszko posadził ją koło siebie, nakrył kołdrą i warknął: - Pójdziesz jutro ze mną do biblioteki, zapiszemy cię... Będziesz mogła sobie czytać, co zechcesz. Tylko słuchaj, głupia, pytaj się, co wybrać! Nie można tak jednego z drugim: poezja i Zagadnienia leninizmu! - Oj, kiedy one bardzo ciekawe, te zagadnienia. - Głupiaś. To nie dla bab. [...] Nie można tak jak dzicy ludzie: co pod ręką... A późno w noc przyłożyła mu wargi do ucha: - Jesteś taki, jak jeden, o którym czytałam. Twardy, myślałby kto, że bez serca, a jednak... Nazywał się, zaraz, Baurdżan Momysz-Uły..." (Ścibor-Rylski, 1952, s. 277).

Język socrealistycznej prozy stawia powieściowe bohaterki w roli uczennic, podwładnych, dzieci, zabawek swych mężów i kochanków. Kobiety nie tylko stają się przedmiotem męskiej infantylizacji, lecz także same deprecjonują własną „kobiecość” jak Janka z Lewantów:

„Wiesz, ja nie myślę o takich zwyczajnych nastrojach babskich, że to lipy, że to romantycznie, że spacer. Bo to niby tak wypada... Ja mówię o poważnych rzeczach... Nie, tfu! - Do cholery! Nie umiem, nie będę mówić - zezłościła się nagle tupiąc nogą i zaciskając piąstki. - Grymasi dziecko - zaczął Leon tonem donżuana" (Braun, 1954b, s. 6).

Mimo że jedyną przestrzenią, w której realizuje się równouprawnienie, jest życie publiczne, nie znaczy to, że kobiecy głos będzie miał w nim siłę równą męskiemu. Oto jak Reczyce z powieści Juliana Gałaja radzą sobie z protestami przeciw elektryfikacji:

„Zamiar elektryfikacji Reczyc wywołał dużo gniewnego krzyku. I najgłośniejszy krzyk podnosiły kobiety. [...] Mimo tych krzyków, okazało się, że elektryfikacja wsi ma najwięcej chętnych. [Kobiecy głos to nie głos? - A.F.] Syn starego Łozy, Antek, złapał za ramiona krzyczącą kobietę, wykręcił ją i wepchnął do domu. Synowa bowiem z sąsiadką wykrzykiwały na dworze. Sąsiad zrobił to samo ze swoją kobietą" (Gałaj, 1953, ss. 52-53).

W męskiej demokracji kobiecy sprzeciw, łatwy do spacyfikowania, niewiele bowiem znaczy.

Uległość pozostaje normą również w sferze erotyki:

„Przyciągnął ją do siebie z całej mocy i trzymając przechyloną i bezwładną zaczął całować, rozgniatając jej usta swoimi. Irka osłupiała, nie broniąc się zupełnie. Po chwili dopiero próbowała odsadzić się całym ciałem od Stacha. Na próżno... Wreszcie Stacho opamiętał się. Puścił dziewczynę, która stała bez tchu, w ogniu. Dyszała ciężko, nie mogąc się odezwać. Na koniec wybąkała: - Jak ... nas tak... kto... zobaczy... - A niech zobaczy - potrząsnął Stacho głową. - Tylko ty możesz mi zabronić cię całować, nikt więcej” (Gałaj, 1953, s. 219). 
Ta scena przedstawia kobietę zarówno całkowicie podległą mężczyźnie - bezwładną, ale też fizycznie niezdolną do oporu. Co więcej, mimo wpisanej w swą naturę bezsilności, zobowiązaną do jego zasygnalizowania. Opór jest tu bowiem tak samo „kobiecy” jak wstyd. Konwencjonalnie mierzy się z siłą, natarczywością i inicjatywą mężczyzny i, konwencjonalnie, skazany jest na porażkę. Seksualnie pobudzony mężczyzna wyzwala tu „naturalną” seksualność w kobiecie. Co interesujące, to również on, mówiąc: „Tylko ty możesz mi zabronić cię całować, nikt więcej”, daje jej prawo dysponowania własnym ciałem, wskazując jednocześnie jego osobliwą interpretację. Bo czymże jest to prawo, jeśli „odpychająca się całym ciałem” kobieta to kobieta zgodna? Czyż nie jeszcze jednym „męskim” wyobrażeniem istoty, która „mówi «nie», ale myśli «tak»”?

\section{Zagubiona owieczka}

W socrealistycznej metaforyce ważne miejsce zajmuje budulec „nowego”, którym w równym stopniu jest „nowy człowiek”, jak i nowy materiał budowlany. Bardzo plastycznie oddaje to powieść Mariana Brandysa, w której i murarz, i partyjny ideolog mają to samo zadanie do wykonania - odnaleźć i uratować „zagubione cegiełki”.

Majster Walaszczyk:

„porzucone w skutek niedbalstwa cegły tropił jak najcenniejszy łup. Podnosił je i układał na innych cegłach, [...] pogadując przy tym do nich czule, jak do małych dzieci pozostawionych bez opieki. [...] Naraz jego uwagę pochłonęła cegła, na którą nastąpił. Jej też poświęcił całą swą troskę. Podniósł ją zważył w rękach, obejrzał ze wszystkich stron i swoim zwyczajem rozgadał się do niej jak do żywego stworzenia: - Porzucili cię, niedbalcy, porzucili samą, jedną. I cóż by z tobą tu stało się, biednieńka. Zmarniałabyś bez pożytku. A tak wmurują ciebie w piękny dom i zestarzejesz się w poszanowaniu, dobrym ludziom na pociechę" (M. Brandys, 1953, ss. 129-130).

Plan sześcioletni w tej metaforyce przedstawiany jest jako „wielka kruszarka”:

„W tej kruszarce przez zęby i tryby przechodzi i dobry kawałek cegły, i stary zardzewiały gwóźdź, i nic niewart szmelc, odpadki. Z tej kruszarki wyjdzie wspaniały materiał na cegłę, a gwoździe zardzewiałe i różne świństwa odrzuci się na bok jako niepotrzebne” (Konwicki, 1952, s. 83).

\section{Jak maszyna}

W socrealistycznej prozie człowiek to narzędzie nowego systemu, wyobrażane za pomocą prostej metafory narzędzia pracy. Bohaterka Samsona tkająca sieć w portowej sieciarni robi to ze sprawnością mechanizmu:

„Drewniana igła z nawiniętym na nią sizalowym sznurkiem szybko migała w palcach Anny. Tam i z powrotem przez kolejne oka sieci. Przełożyć raz, drugi, zostawić luz, przesunąć przez pętlę, zacisnąć węzeł; wetknąć szablon, znów przełożyć dwa razy, znów pętla i węzet i znów i znów... [...] Jeszcze dziesięć oczek... Jeszcze pięć... Jeszcze dwa - jedno... Już! [...]

SLH 2/2013 | str. 387 
I znowu: przełożyć raz, drugi, zostawić luz w pętli, zacisnąć węzeł..." I zostaje doceniona osobliwym, ale znaczącym komplementem: „Anno, pracujesz jak maszyna! [...]” (Meissner, 1952, ss. 53-54).

Ciała ludzkie, będące - jak mówi Mary Douglas - modelami społeczeństwa, w socrealistycznych fabułach odzwierciedlają na poziomie mikro główne założenia ustroju (Douglas, 2007, ss. 149-150). Ciała należące do bohaterów pozytywnych są przede wszystkim produktywne: wyrażają zdolność do pracy, płodność i siły witalne. Krystyna, portowy mechanik, opisywana jest w takich słowach: „Świeże, skore do uśmiechu usta i duże, jasne, zielonkawo-brązowe oczy dodawały jej szczególnego wdzięku. Biła od niej młodość, energia, żywotność" (Meissner, 1952, s. 26). Podobnie Roman Kowalski, który „oczy miał jak węgle, rysy regularne, zniewalający uśmiech na męskiej, ogorzałej gębie, ciemne, połyskliwe, lekko falujące włosy, postawę prostą, swobodną, elastyczną, a przy tym mięśnie jak stalowe sprężyny" (Meissner, 1952, s. 23). Natomiast bohaterowie negatywni, tacy jak Bunc, są zwierzęco pokraczni: „żywo gestykulował swymi małpio długimi rękami” i niezdolni do pracy - podstawowej czynności określającej człowieczeństwo:

„Jego długa, blada twarz nie wyrażała nic zgoła. Wydatna grdyka poruszała się raz po raz jak podczas przełykania. Oczy nieprzytomne, szklane patrzyły nie widząc. Nadmiernie długie ręce zwisały aż do kolan, kołysząc się jak przyczepione na sznurkach” (Meissner, 1952, ss. 137, 142).

\section{Wokót człowieka}

Marksistowski człowiek powołany jest do tego, by poprzez „świadomą i celową, zbiorową i społeczną działalność wytwórczą", czyli pracę, przekształcać własną zwierzęcą naturę i uniezależniać się od przyrody (Jasińska \& Siemieńska, 1978, s. 80). Na poziomie socrealistycznej narracji znajduje to wyraz w próbach tworzenia rzeczywistości wzorowanej na przyrodniczej - po arcimboldowsku lepionej z gumowych, żelaznych czy betonowych części - jednak znacznie od niej potężniejszej, jak kopalnia, której korytarze przypominają rzeczne koryto:

„Podziemia dokoła huczały jak rozpędzona rzeka. Z tyłu, z przodu i z boków grzmiał walący rurami piasek, zabłąkane strumienie szeleściły jak liście między pustymi wózkami, ludzie nawoływali się dzwonieniem w metalowe przewody powietrzne. Czasami w gardle chodnika ukazywała się grupa zamułkarzy podobnych do nurków, z głowami ukrytymi pod brezentem. Posuwali się nierównym krokiem i znikali w mroku dowierzchni. Rzadziej słychać było filtrowany przez węgiel syk pił i turkotanie młotków [RZECZNE PTAKI - SYCZĄ I TURKOCZĄ - A.F.]" (Ścibor-Rylski, 1952, s. 137).

Czy jak huta, która na chwilę zamienia się to w przydomowy sad, to w malowniczy zachód słońca: „Okna korytarza, wychodzące na wschód, były na przemian to malinowe, to wiśniowe, to znów koloru śliwy lub jasnej brzoskwini. Bo tam daleko była huta «Krzyniec» z jej wielkimi piecami, które zabarwiały zmierzch swoją łuną" (Ścibor-Rylski, 1952, s. 129). 
Zgodnie z postulatami teoretyków zmianie najbliższego otoczenia człowieka towarzyszy zmiana estetyki. „Nowi ludzie” w krajobrazie przemysłowym odnajdują piękno i chwile wytchnienia. Sekretarz komórki partyjnej Brzoza i nowy wicedyrektor kopalni Migoń, ciesząc się własnym towarzystwem, wdychają „przez okno lipowy zmierzch z jego ciepłym dymem i wonią żytka" (Ścibor-Rylski, 1952, s. 213)4. Podobną przyjemność z industrialnej przestrzeni czerpią górnicy, którzy na naradę brygad wybrali takie oto miejsce:

„Stare, zaklęsłe pod cegielnią glinianki były do połowy napełnione miętowo-burą wodą. Na powierzchni roztaczała się firanka zmarszczek skubanych przez wiaterek. Wśród wiklin o lakierowanych liściach leżały zbędne, porzucone rury, betonowe cembrowiny, kawały brązowego żelastwa. Górą szedł dym kolejowy z bliskich torów, gdzie świstały oczekujące podróży pociągi. Było tu ciepło, pachniało... Rozsiedli się, jak komu wygodnie. Jędraszko podłożył sobie chusteczkę. Rutka ściągnął buty i moczył krzywe palce nóg w wodzie” (Ścibor-Rylski, 1952, s. 202).

Jeśli powyższy opis podda się próbie rekonstrukcji metaforycznej, scena zupełnie zmieni charakter. Okaże się, że: GLINIANKI TO JEZIORKO, WIATEREK/PACHNIAŁO/CIEPŁO/ ROZSIĄŚĆ SIĘ TO PRZYJEMNIE, FIRANKI TO SWOJSKO, ROZTACZAĆ TO PIĘKNY WIDOK, ELEMENTY INDUSTRIALNE TO ZWIERZĘTA/ROŚLINY, DYM TO CHMURY, ŚWIST POCIĄGÓW TO PTAKI. Tym samym krajobraz stanie się tłem do bardzo konwencjonalnego sposobu na relaks, mianowicie wypoczynku nad jeziorem.

Przemieniająca moc ludzkiej pracy przekształca nie tylko najbliższe otoczenie, ale również inne stworzenia. Socrealistyczną prozę wypełniają zwierzęta - maszyny, bliżej nieokreślone byty o nadludzkiej sile: „Motor ryczał dziko. [...] Ford zahaczywszy tylnym błotnikiem o palik furtki, wypełzł przed ogródek. [...] Bucząc jak pszczoła robił wiraż na wiadukcie przerzuconym w poprzek torów kolejowych [SAMOCHÓD TO BESTIA / TO PSZCZOŁA - A.F.] albo: „Maszyna spłynęła lekko z chodnika i skoczyła w głąb ulicy między dwa rzędy światełek, sypiąc blaskiem reflektorów po przydrożnych słupach [SAMOCHÓD TO ZWIERZĘ - A.F.]" (Ścibor-Rylski, 1952, ss. 221, 88).

Stworzenia żywe w socrealistycznej prozie to istoty całkowicie podporządkowane człowiekowi, przeważnie służące charakterystyce jego zachowań czy ilustrujące powieściowe sceny. Takie funkcje spełniają zwierzęta domowe, których obecność w powieściowych fabułach wskazuje zwykle na silną więź ze światem przyrody, zakazanej erotyki czy rzeczywistości nieprzekształconej przez twórcze moce pracy.

Prawdziwy bohater socrealizmu patrzy na pozaczłowiecze życie niczym na maleńkiego robaczka na dłoni, którego istnienie zaczyna być faktem dopiero od momentu, gdy znajdzie się w obszarze ludzkiego poznania. Tę myśl, która wyraża w bardziej uniwersalnym sensie stosunek człowieka do świata i charakter samego procesu poznania, oddaje bardzo niepozorna scena z górniczej narady: w trakcie spotkania zespołu „Felek dogrzebał

4 Tu warto zwrócić uwagę także na drugi obok, jak można przypuszczać, przemysłowego „ciepłego dymu” element zapachowej kompozycji - żyto, w bardzo szczególny sposób nawiązujący do socrealistycznego postulatu sojuszu robotniczo-chłopskiego. 
się patyczkiem dżdżownicy, wydobył ją na światło, położył na dłoni” (Ścibor-Rylski, 1952, s. 202) [POZNAĆ TO OŚWIETLIĆ, POZNAĆ TO WYDOBYĆ, POZNAĆ TO UMIEŚCIĆ WE WŁASNYM ŚWIECIE - A.F. (Ricoeur, 1975, s. 249)] $]^{5}$.

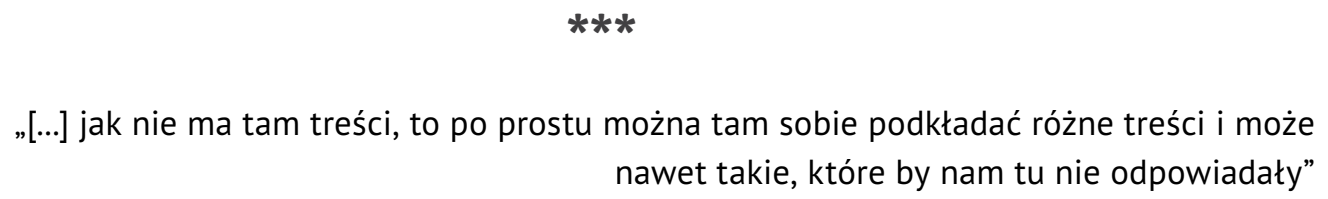

Rejs

Jeszcze nie udzielono ostatecznej zgody na umieszczenie socrealistycznej prozy w zasięgu polskiego czytelnika. Socrealizm dopiero zaczyna być oglądany, ostrożnie, z uwagą, z prześmiewczym dystansem, ale często bez próby zrozumienia. Socrealistyczne dziwy siłą smaku na opak powoli, krok po kroku wkradają się do przestrzeni współczesnego poznania. Dochodzi jednak do nowego poznawania socrealizmu, nie dlatego - wbrew słowom Michała Głowińskiego - że nauka o kulturze przestała mieć wymiar wartościujący, lecz przeciwnie: dlatego, że zaczęła na to wartościowanie patrzeć z dystansem (Głowiński, 1992, s. 5). To dystans o dwóch twarzach: narzędzia poznawczego i poznawczej bariery.

Postawa dystansu, wedle Bourdieu, odwołuje się do modelu percepcji estetycznej, charakteryzującej się zdolnością postrzegania rzeczy jako „samych w sobie i samych dla siebie, w swojej formie, a nie funkcji”. Przeciwstawiona jest właściwemu dla smaku ludowego postrzeganiu świata w wymiarze afektywnym i etycznym (Bourdieu \& Passeron, 2006, ss. 11, 59). Jej wyrazem jest smak refleksyjny: kompetencja oddzielania formy od treści w stopniu skrajnym wyrażająca się „zachwytem” nad tym, co „nie zachwyca”, tym, co jest czystym zaprzeczeniem „piękna” i „normy”, tak jak socrealizm jest „antywartością" i „antykulturą”.

To zachwyt na opak, w którym „piękne” okazuje się „patriarchalne” równouprawnienie płci, władza ludu (która, dehumanizując, zamienia jednostki w narzędzia pracy), projekt wielkiej odnowy (którego istotą jest wielkie niszczenie) czy wreszcie puste półki w sklepach i jedzenie na kartki. Współczesnym przejawem owego „zachwytu” jest rosnące zainteresowanie całym okresem PRL-u w różnych jego aspektach, wyrażane zarówno przez nastolatka ubranego w markowy ciuch z nadrukiem inspirowanym powojennym plakatem, rodzinę zafascynowaną Kolejkq - IPN-owskim bestsellerem wśród gier familijnych, jak też publicystę, który, aby mówić o tzw. równouprawnieniu kobiet, zaczyna od tych, co w latach pięćdziesiątych miały siadać na traktory. Wszyscy wymienieni porzucają „treść” - i tę wyrażaną w komunikatach wytworzonych w powojennym czterdziestoleciu, i tę,

5 Ten szczególny związek oświetlania jako wprowadzania do przestrzeni własnego poznania, do własnego świata, ma korzenie w etymologicznym związku słów świat" i światło". W językach słowiańskich polski ś́wiat”, czeski „svět” czy rosyjski „svet” mają rodowód w prasłowiańskim odczasownikowym rzeczowniku „světb” ('światło'), po"chodzącym od "svisti” ('świecić', 'oświetlać') i od praindoeuropejskiego „k'uei-t-” ('świecić', "jasny', 'biały'). Stowo „świat” miało rozwiną́ się z pierwotnego „światło” poprzez takie wyrażenia, jak „ujrzeć światło dzienne” ("urodzić się, przyjść na świat') czy „wyjść na światło dzienne” ('stać się jawnym, znanym ludziom, światu') (por. Boryś, 2005, s. 621; Długosz-Kurczabowa, 2008, ss. 646-648). 
którą socrealizmowi i całemu PRL-owi nadała dotychczasowa kultura - aby pochylić się nad jego formą.

„Smak czysty”, który w przeciwieństwie do „estetyki ludowej” potrafi wyzwolić formę z jej funkcji oraz „treści” etycznej lub zmysłowej, ma objawiać się poprzez umiejętność postrzegania socrealistycznej „wytwórczości” w postaci wolnej od moralnych ocen i wartościowania - „bez uprzedzeń”, jak mówią lewicowi publicyści (Majmurek \& Szumlewicz, 2010, s. 7). Parafrazując Witkacego, można powiedzieć: „Patrzcie na socrealizm nie jako na kawałek natury, ale jako na konstrukcje czystej formy, na oderwane piękno, a będziecie go rozumieli jak należy”. „Zachwyt”, jaki zakłada owo podejście - można by je za Rortym nazwać podejściem „ironistki” - daje dostęp do tych obszarów socrealistycznych światów, które dla oka poszukującego jedynie „treści” pozostają zamknięte.

Uprawomocniająca siła Bourdieu'owskiego dystansu, za sprawą której socrealizm staje się obiektem zainteresowania elit, ma niewątpliwie ogromne znaczenie jako narzędzie poznawcze. Odczarowuje zakazany temat, a zarazem stwarza przestrzeń do jego pogłębionego oglądu. Bowiem, jak pisze Hans-Georg Gadamer, odnoszenie się do świata ze zrozumieniem wymaga dystansu do tego, co w nim spotykane po to, by można było to sobie przedstawić takie, jakie to jest (Gadamer, 2007, s. 596).

Współczesna zabawa socrealizmem, w którą z jednej strony wpisuje się otwieranie na niepokój socrealistycznych (u)tworów, z drugiej zamykanie w przestrzeni stereotypowych wyobrażeń o przodownikach i dzielnych traktorzystkach, jest odkrywaniem socrealistycznej terrae incognitae przy jednoczesnym odgradzaniu się od niej barierą ironii.

Ironia jest dziś domyślnym narzędziem obserwacji socrealistycznej rzeczywistości, niemal wpisanym w samą „naturę” tematu. Bo jak inaczej mówić o przodowniku pracy, nowych domach na święto 22 lipca czy „traktorach, które zdobędą wiosnę”, jeśli nie z przymrużeniem oka? Bo jak subtelniej wypowiedzieć wojnę socrealistycznemu językowi, jeśli nie wykorzystując jego własną broń, co zrobił Ważyk w swym najsłynniejszym wierszu: „Fourier uroczo zapowiadał, że w morzach będzie pływać lemoniada./ A czyż nie płynie?/ Piją wodę morską,/ wołają - lemoniada!" (Ważyk, b.d., 12,1-6).

Ironia współczesnych komentatorów bywa więc nie tyle przejawem dystansu, ile przede wszystkim doskonałym narzędziem chroniącym „smak czysty” przed kompromitującą demaskacją. Ironia, jak zauważa Agnieszka Doda, „służy tworzeniu dystansu pomiędzy podmiotem wypowiedzi i wypowiedzią samą” przy założeniu, że „mówiący jakby nie bierze odpowiedzialności za swe słowa. Tylko «jakby»" (Doda, 2004, s. 7). Wydaje się, że w dzisiejszym postrzeganiu socrealizmu owo „jakby” też jest kluczowe. Pozwala zarówno na dobrze zamaskowany „zachwyt”, jak i na równie dobrze ukryte potępienie. Dopuszcza więc zarazem ocenę etyczną, nieuchodzącą przecież w otwartej mowie (Bourdieu \& Passeron, 2006, s. 41), i pewien poziom - przynajmniej poszukiwania - (nie)przyjemności zmysłów (Bourdieu \& Passeron, 2006, s. 597). 
Badanie i wykorzystywanie socrealizmu, wbrew intencjom jego twórców, odbywa się zatem pod hasłem „niezaangażowania”, w istocie będącego „zaangażowaniem” na nowo, a zatem zaangażowaniem w nowe dyskursy. Pozbawienie socrealizmu historycznej i kulturowej treści jest wypełnieniem go nową, nie mniej znaczącą. Socrealizm jako antywartość nie znika zatem z pola widzenia, przeciwnie - w nowym kontekście daje o sobie znać z większą jeszcze siłą. Pytanie tylko, czy jako taki istotnie ma szansę sam stać się przedmiotem refleksji, czy jedynie „ideologią” w ręku innej, lepiej ukrytej?

\section{Bibliografia}

Althusser, L. (2006). Ideologie i aparaty ideologiczne państwa. (A. Staroń, Tłum.). Warszawa: Studenckie Koło Filozofii Marksistowskiej UW.

Bikont, A., \& Szczęsna, J. (2006). Lawina i kamienie. Pisarze wobec komunizmu. Warszawa: Prószyński i S-ka. Boryś, W. (2005). Słownik etymologiczny języka polskiego. Kraków: Wydawnictwo Literackie.

Bourdieu, P. (2005). Dystynkcja. Społeczna krytyka władzy sądzenia. (P. Biłos, Tłum.). Warszawa: Wydawnictwo Naukowe Scholar.

Bourdieu, P., \& Passeron, J.-C. (2006). Reprodukcja. Elementy teorii systemu nauczania. (E. Neyman, Tłum.). Warszawa: PWN.

Brandys, K. (1955). Obywatele. Warszawa: Czytelnik.

Brandys, M. (1953). Początek opowieści. Warszawa: PIW.

Braun, A. (1954a). Lewanty (T. 1). Warszawa: Czytelnik.

Braun, A. (1954b). Lewanty (T. 2). Warszawa: Czytelnik.

Długosz-Kurczabowa, K. (2008). Wielki słownik etymologiczno-historyczny języka polskiego. Warszawa: PWN.

Doda, A. (Red.). (2004). Powaga ironii. Toruń: Wydawnictwo Adam Marszałek.

Douglas, M. (2007). Czystość i zmaza. (M. Bucholc, Tłum.). Warszawa: PIW.

Dróżdż-Satanowska, Z. (1953). Opowieść wierzbowa. Warszawa: Czytelnik.

Fatyga, B., \& Zieliński, P. (2006). Tempus Fugit. Analiza metafor czasu - propozycja metodologiczna. Przegląd Socjologii Jakościowej, 1. Pobrano z http://www.qualitativesociologyreview.org/PL/index_pl.php

Gadamer, H.-G. (2007). Prawda i metoda. Zarys hermeneutyki filozoficznej. (B. Baran, Tłum.). Warszawa: PWN.

Gałaj, J. (1953). W rodzinie Lebiodów. Warszawa: Czytelnik.

Głowiński, M. (1992). Rytuat i demagogia: trzynaście szkiców o sztuce zdegradowanej. Warszawa: OPEN.

Gombrowicz, W. (1987). Ferdydurke. Kraków: Wydawnictwo Literackie.

Jäkel, 0. (2003). Metafory w abstrakcyjnych domenach dyskursu. Kognitywno-lingwistyczna analiza metaforycznych modeli aktywności umysłowej, gospodarki i nauki. (M. Banaś \& B. Drąg, Tłum.). Kraków: Universitas.

Jasińska, A., \& Siemieńska, R. (1978). Wzory osobowe socjalizmu. Warszawa: Książka i Wiedza.

Konwicki, T. (1952). Przy budowie. Warszawa: Czytelnik.

Krzyżanowski, J. (Red.). (1969). Nowa księga przysłów i wyrażeń przysłowiowych polskich (T. 1). Warszawa: PIW.

Lakoff, G., \& Johnson, M. (2010). Metafory w naszym życiu. (T. Krzeszowski, Tłum.). Warszawa: Aletheia.

Majmurek, J., \& Szumlewicz, P. (Red.). (2010). PRL bez uprzedzeń. Warszawa: Instytut Wydawniczy „Książka i Prasa".

SLH 2/2013 | str. 392 
Mannheim, K. (2008). Ideologia i utopia. (J. Miziński, Tłum.). Warszawa: Aletheia.

Meissner, J. (1952). S/T Samson wychodzi w morze. Warszawa: Książka i Wiedza.

Newerly, I. (1953). Pamiątka z Celulozy. Warszawa: Czytelnik.

Piekara, M. (2001). Bohater powieści socrealistycznej. Katowice: Wydawnictwo Gnome.

Ricoeur, P. (1975). Zdarzenie i sens wypowiedzi (E. Bieńkowska, Tłum.). W S. Cichowicz (Red.), Egzystencja i hermeneutyka. Rozprawy o metodzie (ss. 239-251). Warszawa: PAX.

Sławiński, J. (Red.). (1988). Słownik terminów literackich. Wrocław: Zakład Narodowy im. Ossolińskich.

Szacki, J. (1991). Ideologia. W J. Szacki, Dylematy historiografii idei oraz inne szkice i studia. Warszawa: PWN.

Ścibor-Rylski, A. (1952). Węgiel. Warszawa: Książka i Wiedza.

Tokarska-Bakir, J. (1992). Hermeneutyka gadamerowska w etnograficznym badaniu obcości. Polska Sztuka Ludowa. Konteksty, 1, 3-17.

Tokarska-Bakir, J. (2014). Komentarz metodologiczny: hermeneutyka filozoficzna jako pomoc w etnograficznym badaniu obcości. W J. Tokarska-Bakir, Wyzwolenie przez zmysły. Tybetańskie koncepcje soteriologiczne (2. wyd.). Toruń: Wydawnictwo Naukowe UMK.

Tomasik, W. (1988). Polska powieść tendencyjna 1949-1955. Problemy perswazji literackiej. Wrocław: Zakład Narodowy im. Ossolińskich.

Tomasik, W. (1991). Stowo o socrealizmie. Szkice. Bydgoszcz: Wydawnictwo Uczelniane WSP.

Toniak, E. (2008). Olbrzymki: kobiety i socrealizm. Kraków: Korporacja Ha!art.

Walat, T. (2013, luty 13). Sukces turystyki kryminalnej w Szwecji. Polityka. Pobrano z http://www.polityka.pl/tygodnikpolityka/swiat/1523991,1,sukces-turystyki-kryminalnej-w-szwecji.read

Ważyk, A. (b.d.). Poemat dla doroslych (pierwodruk: „Nowa Kultura” z 21.08.1955). lewicowo.pl. Pobrano z http://lewicowo.pl/poemat-dla-doroslych/

Żukrowski, W. (1953). Mądre zioła. Warszawa: PIW.

\section{But... These worlds are tendentious}

\footnotetext{
Abstract: The article focuses on the term tendentious novel and its special use in the Polish literary theory: the context of socialist realist novels. Taking into consideration Louis Althusser's concept of ideology and Pierre Bourdieu's theory of pure and impure taste, the article calls into question the idea of tendentiousness in discourse, and categorising novels as "strongly saturated with ideology" and therefore labelling them as "tendentious". The inspiration to write this paper was the perception of socialist realism in Poland, with particular reference to Stalinist novels, whose forgotten senses and unknown but universal metaphoric systems are presented by the author.

Keywords: tendentious novel, socialist realism, ideology, disgust, world transformation
} 